\title{
Justice, legitimacy and self-determination: Moral foundations for international law
}

\author{
Allen Buchanan \\ Oxford University Press, Oxford, 2007, 520pp., \\ ISBN: 0198295359
}

Contemporary Political Theory (2009) 8, 111-112. doi:10.1057/cpt.2008.33

For everyone interested in political theory and global justice, Buchanan's Justice, legitimacy and self-determination: Moral foundations for international law is an essential read. It offers an insightful general theory of international justice and it also represents the fullest statement of Buchanan's political theory to date and does so in a manner that befits its place in the excellent OUP political theory series. It is a book that explores the key issues of humanitarian intervention, distributive justice, global governance, secession and state breakdown and situates the argument in a holistic exploration of the central question of whether peace or justice should be the goal of international law. The appeal of this book goes further than the fact that it engages with the most urgent issues in world affairs. As a work of normative political theory, it promises an innovative approach to the way political theory explores questions of global justice. The major promise of this ambitious book is that it will be an engagement with moral theory and with the law as it exists and with the institutions of the International Legal Order; and that this will be an argument that crosses the boundaries between Public International Law and moral and political theory.

While the work of constructivists in international political theory belies the claim that the linkage between theory and practise is unique to Buchanan's political thought, I do think that, when we limit the field to liberal political theory, Buchanan is attempting to do something very distinctive. The interplay between moral theory and the institutions of the international legal order is the bedrock of Buchanan's account of secession, humanitarian intervention, state legitimacy and his critique of the UN (that is, all the interesting practical stuff). It also forms the basis of the working parts of his argument - the Moral Theory of International Law (outlined in the superb first chapter that orientates the reader) and the associated demand for a human rights-based conception of justice applied through institutional moral reasoning.

It is that last phrase - institutional moral reasoning - that is central to Buchanan's case. He argues that a defensible moral theory of international law must take into account that fact that moral principles of international law are institutional principles. The critical heart of this challenging book is the idea that a liberal conception of international justice has to relate to existing 
institutions in a critical but responsible manner (Buchanan characterizes this as progressive conservatism). Liberals have to recognize, Buchanan argues, that the existing international order has limited resources for reform and they must take a politically sensitive view of when illegal actions (for example, humanitarian interventions or third party recognition of the sovereignty of a secessionist state) are required to promote system-reform. The idea that we need to focus on what Buchanan calls the morality of transition (something he has elsewhere called illegal, legal reform) and the claim that institutional moral reasoning has the tools to help is tremendously promising and offers the potential to connect contemporary liberal cosmopolitanism to the central debates in international relations. Buchanan makes it clear that international justice is always about intermediate goal setting and the morality of transition and his innovative framework is precisely what we need when we think about the relation between principles and practise in global affairs. In this reader's opinion it is this set of ideas that will prove to be of most significance in the debates that must follow the publication of this valuable treatise.

This focus does not dilute Buchanan's cosmopolitanism. Theoretically, his human rights-based conception of justice is an unreformed neo-Kantianism that underwrites what he calls the natural duty of justice argument. His political prescriptions are also more progressive than conservative. He calls for major reforms to the law relating to the recognition of states and to that concerning unilateral secession that places human rights at the core of state legitimacy. $\mathrm{He}$ boldly calls for a 'liberal-democratic, rule governed, treaty-based coalition for humanitarian intervention that would be 'elitist' at least in its initial form, insofar as it would bypass the more inclusive UN-based system of law' (p. 326); a coalition, not of the willing, but of the just. He also denies the moral importance both of the state consent model of international law and, more generally, the United Nations and even more developed democratic global governance mechanisms. Again it is human rights that trump the instrumental value of the state consent model.

The key to this book is the interplay between Buchanan's cosmopolitanism, which is unremarkable in itself, and the innovative approach to institutional moral reasoning. Buchanan claims that buying in to his natural duty of justice is not necessary for the reader to accept his 'progressive conservatism' (p. 97). This may be true but I am not certain that, without the stronger foundational claims, the reader will follow the path to the rather bold political claims made by the author. However, making that judgment is for the individual reader and everyone who makes the effort will gain a significant range of insights into the relationship between international justice and international law regardless of their view.

Peter Sutch, Cardiff University, UK 